\title{
Profesor Jan Janoušek slaví životní jubileum
}

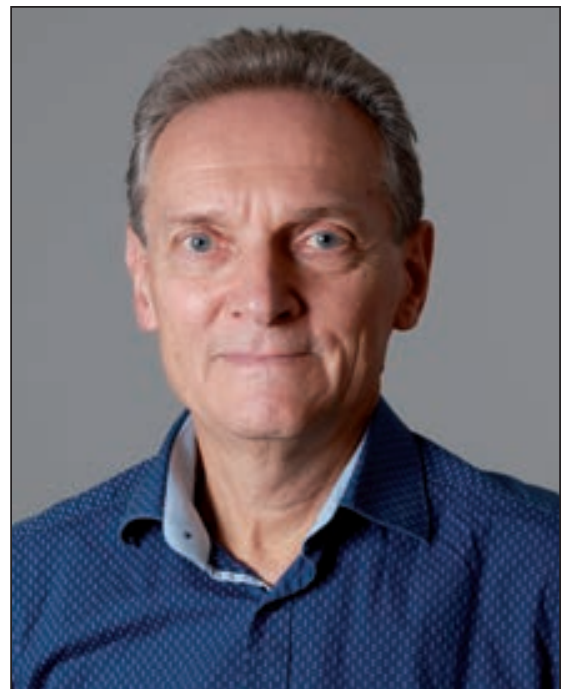

Pan profesor MUDr. Jan Janoušek, Ph.D., přednosta Dětského kardiocentra 2. LF UK a FN v Motole, se 26. 5. 2021 dožívá 65 let. Narodil se v Praze, maturoval pak v Českých Budějovicích, vystudoval Fakultu dětského lékařství Univerzity Karlovy v Praze, promoval v roce 1981. Po promoci začal pracovat jako sekundární lékař Dětského kardiocentra FN v Motole pod vedením velikána dětské kardiologie, profesora Milana Šamánka. Od roku 1988 se již více věnoval problematice arytmologie jako vedoucí lékař úseku elektrofyziologie a kardiostimulace, předtím složil atestace I. stupně z pediatrie a poté i z dětské kardiologie. Po absolvování odborných stáží na oddělení dětské kardiologie, Medizinische Hochschule Hannover, SRN a na oddělení dětské kardiologie, Children's Hospital, Texas Medical Center, Houston, Texas, USA v roce 1991 se stal na devět let vedoucím lékařem poooperační JIP Dětského kardiocentra FN v Motole. Odtud pak přešel na pět let do funkce přednosty Kliniky dětské kardiologie, Herzzentrum, Univerzita v Lipsku. Po návratu do České republiky pracoval nejprve jako vedoucí lékaŕ úseku elektrofyziologie a kardiostimulace Dětského kardiocentra
FN v Motole (2009-2011) a od roku 2011 až do současné doby je pak přednostou tohoto dětského kardiocentra. Habilitoval v roce 2001 (2. LF UK Praha) a profesorem pro dětskou kardiologii byl jmenován v roce 2005 (Univerzita v Lipsku). Jeho hlavní oblastí zájmu je diagnostika a léčba poruch srdečního rytmu u dětí, což se samozřejmě odráží i v činnosti publikační - sepsal tři monografie, šest kapitol v monografiích, v roce 2021 je evidováno 100 publikací na Web of Science, z toho u 22 je prof. Janoušek uveden jako první autor. Citovanost dle WOS bez autocitací: 4026. $\mathrm{H}$ index dle WOS: 29.

Honza Janoušek je členem řady odborných společností, na prvním místě vždy uvádí Českou kardiologickou společnost (je jejím čestným členem), dále je členem České pediatrické společnosti ČLS JEP, České společnosti anesteziologie, resuscitace a intenzivní medicíny ČLS JEP, z těch zahraničních je členem Association for European Pediatric and Congenital Cardiology, European Society of Cardiology, European Heart Rhythm Association, Deutsche Gesellschaft für Paediatrische Kardiologie a Pediatric and Congenital Electrophysiology Society. V řadě odborných společností zastával a zastává významné funkce, např́ílad byl předsedou pracovní skupiny Pediatric arrhythmias and Electrophysiology při Association for European Pediatric Cardiology (AEPC) a členem výboru AEPC (v minulosti), místopředsedou výboru České kardiologické společnosti (od roku 2011), členem výboru České asociace pro srdeční rytmus a predsedou Pracovní skupiny pediatrické kardiologie České kardiologické společnosti. Je členem výboru České asociace preventivní kardiologie a výboru Pracovní skupiny chlopenní a vrozené srdeční vady v dospělosti ČKS.

V současné době je hlavním organizátorem tradiční akce pediatrů - „Šamánkových Poděbrad“, tuto funkci převzal po svém učiteli Milanu Šamánkovi, s nímž ho pojilo dlouholeté prátelství. Spolupracovat a setkávat se s Honzou Janouškem je vždy příjemné, vyzařuje vrozenou noblesu a věřím, že se s ním budeme ještě dlouho setkávat i v letech budoucích. Za výbor české kardiologické společnosti si dovoluji popřát hlavně dobré zdraví a mnoho let krásné práce v oboru dětské kardiologie.

Srdečně, Michael Aschermann 